\title{
Arthroscopic Assisted Management of Tibial Plateau Fractures
}

\author{
AHMED N. MORRAH, M.D.; KHALED SHOHAYEB, M.D.; HISHAM MISBAH, M.D.; \\ SABRY M.H. MANAA, M.D.; TAREK BIN ZIADMOURAD, M.D.; MOSTAFA M. SAAD, M.D.; \\ MOHAMED KAMAL, M.Sc. and HANY R. ANWAR, M.Sc.
}

The Department of Orthopedic Surgery, Faculty of Medicine, Cairo University

\begin{abstract}
Background: The arthroscope has long been recognized as a useful aid in the management of intraarticulartibial plateau fractures. The following study will clarify 50 cases of tibial plateau fracture types (I,II and III) present a rationale for arthroscopic reduction and internal fixation (ARIF), and review surgical techniques, results, and pitfalls.
\end{abstract}

Aim of Study: This study evaluated the outcome of arthroscopy-assisted reduction with internal fixation for treating tibial plateau fractures.

Patients and Methods: Fifty patients with tibial plateau fractures treated by arthroscopy-assisted reduction with internal fixation (ARIF) were enrolled in this prospective study. According to the Schatzker classification, the fractures types were as follows: Type I, 17; type II, 14; type III, 15 \& type $\mathrm{V}, 4$. The mean age at operation was 28 years (range, 19 to 58 years). The mean follow-up period was 10 months (range, 6 to 12 months). Clinical and radiologic outcomes were scored by the Rasmussen system.

Results: The mean postoperative Rasmussen clinical score was 26 (range, 19 to 30), and the mean radiologic score was 17 (range, 12 to 18). Good or excellent clinical and radiologic results were achieved in $96 \%$ of patients.

Conclusions: (ARIF) for tibial plateau fractures is a safe, reproducible, and effective procedure that provides precise diagnosis and effective treatment in a 1-stage procedure.

Key Words: Tibial plateau fracture - Arthroscopy - Assisted reduction - Internal fixation.

\section{Introduction}

ALTHOUGH tibial plateau fractures comprise only $1 \%$ of all fractures, displaced fractures and the broad spectrum of associated injuries can have severe consequences if not properly treated. In any case, successful results depend on quality of reduction, ligament stability, treatment of associated soft-tissue injuries, and preservation of the soft-

Correspondence to: Dr. Ahmed N. Morrah,

The Department of Orthopedic Surgery, Faculty of Medicine, Cairo University tissue envelope; in addition, good visualization of the articular surface with minimal dissection can help to achieve the desired goal [1]. Surgical treatment has gone through various phases, and arthroscopy-assisted minimally invasive surgery is the most attractive treatment option among surgical treatments [1]. The advantages of arthroscopic reduction-internal fixation (ARIF) for tibial plateau fractures are direct visualization of intra-articular fractures, accurate fracture reduction, reduced morbidity in comparison to arthrotomy, simplified diagnosis and treatment of meniscal and ligamentous injuries, and thorough joint lavage and removal of loose fragments [2]. We hypothesized that arthroscopy-assisted surgery for tibial plateau fractures could provide accurate fracture reduction, stability, and minimal dissection, with a satisfactory outcome. The purpose of this study was to evaluate the clinical and radiologic outcomes of ARIF for treating tibial plateau fractures at 6- to 12-months follow-up.

\section{Patients and Methods}

In the period between August 2010 and June 2013, 50 consecutive patients ( 32 males $\& 18$ females) with closed lateral tibial plateau fractures who had undergone arthroscopic assisted surgery were enrolled in this prospective study. All of them underwent the same treatment protocol for arthroscopic-assisted surgery with percutaneous screw or buttress plate fixation for closed lateral tibial plateau fractures. The average age at operation was 27.48 years (range, 19 to 56 years), followup period had ranged from (6-12) months with an average of 10 months. Using the Schatzker classification, there were 17 type I, 14 type II, 15 type III and 4 type V. The mechanism of injury wasas the following:

Sixteen fractures were the result of a road traffic accident (R.T.A.); Twenty one were the result of 
a fall from different heights; twelve of different sports injuries. Indications for operative fixation included any varus instability exceeding $10^{\circ}$ of lateral plateau fracture with valgus instability exceeding $10^{\circ}$ and articular step-off exceeding $3 \mathrm{~mm}$ or tibial condylar widening exceeding $5 \mathrm{~mm} \mathrm{[3]}$ Patients were excluded if they had any of the fol- lowing features: A pathologic fracture, Open fracture, dislocation, associated neurovascular injuries, severely debilitated patients, highly comminuted plateau and proximal metaphyseal fracture (type IV, V\&VI). Patients with previous infection of knee joint. Numerous classification systems that have been proposed to describe tibial plateau fractures.
(A)

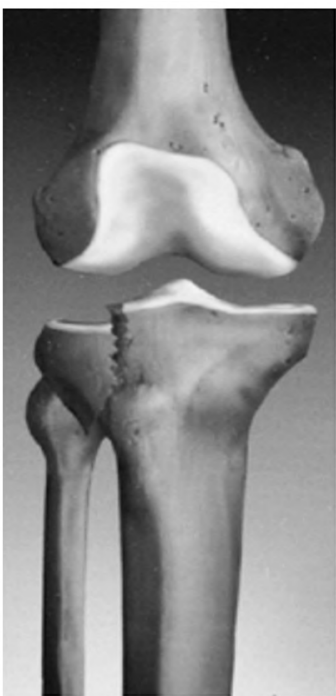

(D)

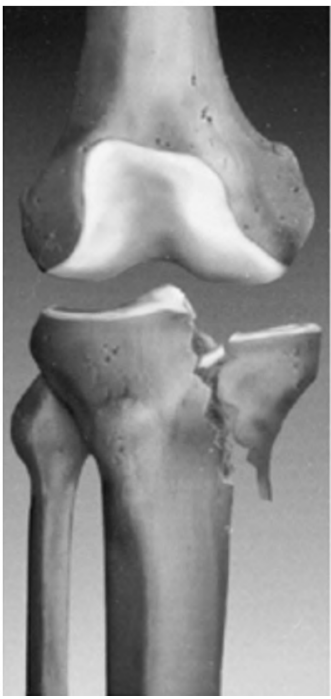

(B)

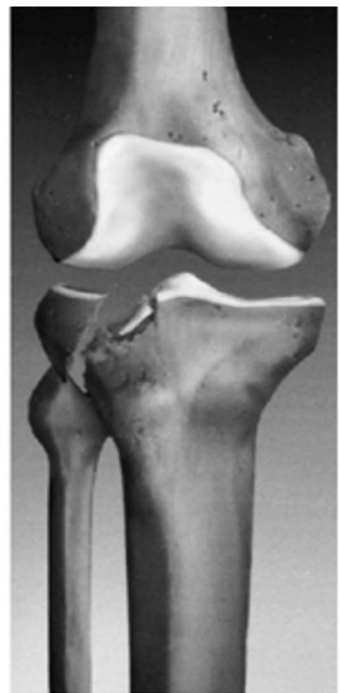

(E)

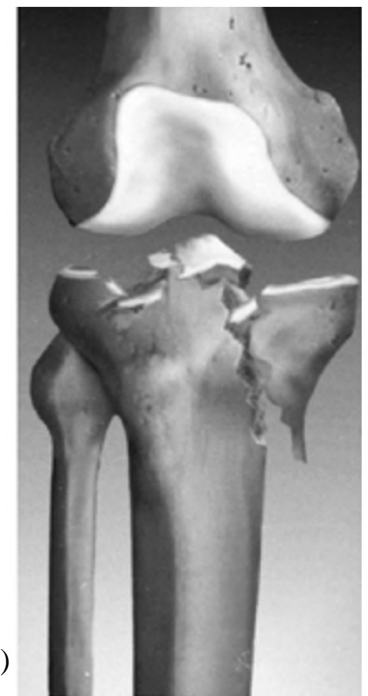

(C)

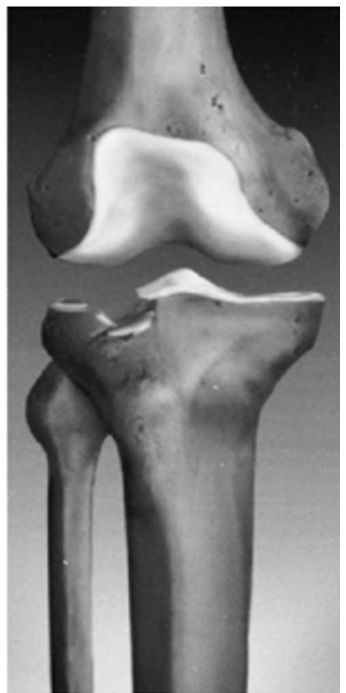

(F)

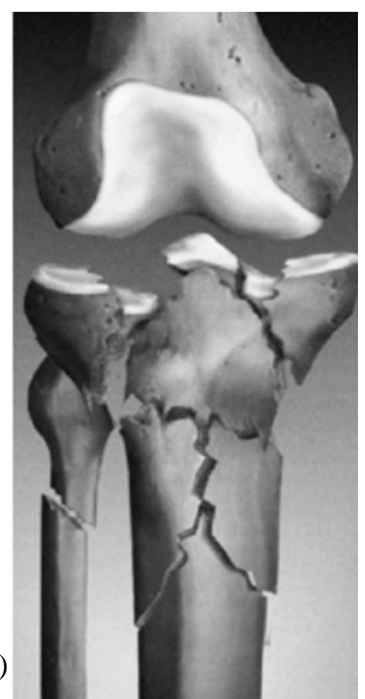

Fig. (1): Schatzker's classification [5]

Schatzker's classification is the mostwidely used; it was the first to make the distinction between medial and lateral plateau, the fracture was classified into 6 types, the first 3 types were concerned with lateral plateau as shown in Fig. (1) \& Tables $(1,4)$.

\section{Table (1): Schatzker's classification.}

\begin{tabular}{llll}
\hline I & Pure cleavage & II & Cleavage and depression \\
III & Pure central depression & IV & Medial condyle \\
V & Bicondylar & VI & Meta- / diaphyseal \\
\hline
\end{tabular}

Preoperative evaluations included detailed physical examination of the condition of the soft-tissue envelope, sensorimotor function of the limb, exclusion of compartment syndrome and vascular status in terms of pulsation over the dorsalis pedis and posterior tibialis arteries. All patients underwent plain film study in anteroposterior and lateral views as well as computed tomography of each knee.

The readiness of the soft-tissue envelope was determined by resolution of swelling marked by the return of skin wrinkles, re-epithelialization of fracture blisters, and reduction of edema [6] 


\section{Surgical technique:}

The patients were positioned supine on the operating table and given spinal or general endotracheal anesthesia. A pneumatic tourniquet is placed at the root of the limb and two separate sterile drapes are chosen to facilitate access to the iliac crest for bone graft collection if required Fig. (2). The anterolateral and anteromedial portals were used to insert the arthroscope as well as working instruments.

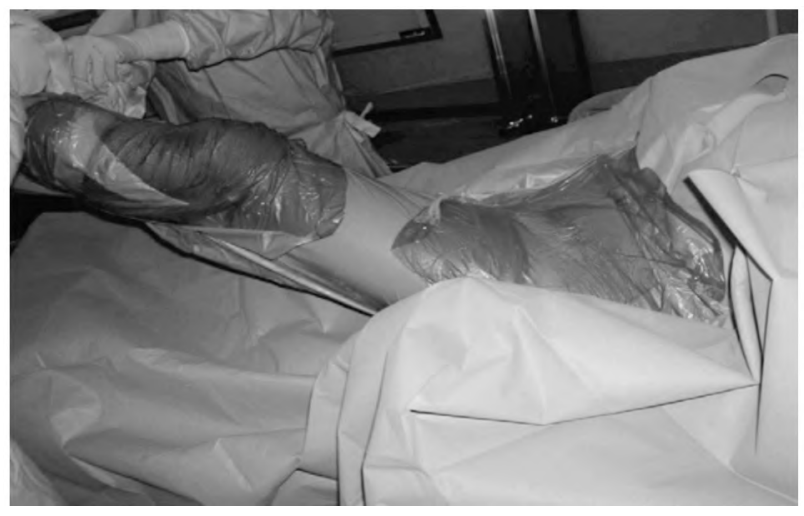

Fig. (2): A useful precaution consists in draping the iliac crest to allow collection of bone graft.

Fluid extravasation was not problematic because inflow was achieved by gravity. The arthroscopic joint inspection permitted evacuation of the he-

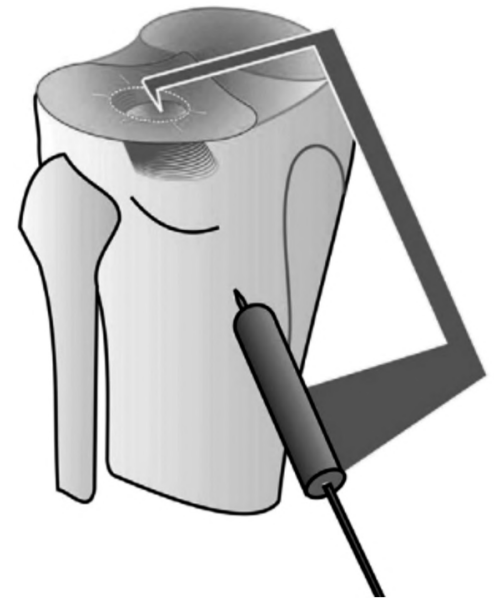

matoma and loose bodies during the initial procedure [6]. The capsuloligamentous structures were then probed, and the associated intra-articular lesions were evaluated.

\section{A- Schatzker Type I Fractures (Lateral Split):}

In this study there were seventeen patients with this fracture type all of them were treated successfully under fluoroscopic control, using the joystick and ligamintotaxis principle to tilt the fracture percutaneously to achieve optimal reduction; followed by holding the plateau by large bone holder clamp and percutaneous two screws fixation. However, the potential added benefit of the arthroscope were the management of six menisci were injured among these seventeen fractures, this is beside hematoma evacuation, removal of smaller chondral fragments, and direct visualization of the joint.

\section{B- Schatzker Type II Fractures (Lateral Split With Depression):}

The basic tools of A.C.L reconstruction were used for reduction of 14 patients with type II fracture as the basic sequence involved initially placing a guide wire up through metaphyseal bone to the apex of the fragment using an A.C.L guide; Once position is checked arthroscopically, the cortical window is created with a serrated Hollow Trephine Cutter or reamer up to within $10 \mathrm{~mm}$ in diameter, to $2 \mathrm{~cm}$ below the depression [7]

Fig. (3): Use of (ACL) guide to target the centre of the depression.

To cut out a cancellous bone core, which is then gently packed subchondrally using a bone tamp $8 \mathrm{~mm}$ in diameter; elevation was performed very gently, under fluoroscopic and arthroscopic guidance. Once the reduction was obtained temporary stabilization was achieved using one or two pins introduced $1 \mathrm{~cm}$ below the joint surface. Pin position was evaluated on anteroposterior and lateral fluoroscopy views (Fig. 4) [7].
After impaction of autologous iliac crest bone grafting from the iliac bone; Lateral buttress plates were used for fixation of comminuted depressed articular surface with split fracture type, using minimal invasive technique; whilepercutaneously two/three cancellous or cannulated screws were used for fixation of fractures with milder degrees of depression and have less comminution. 

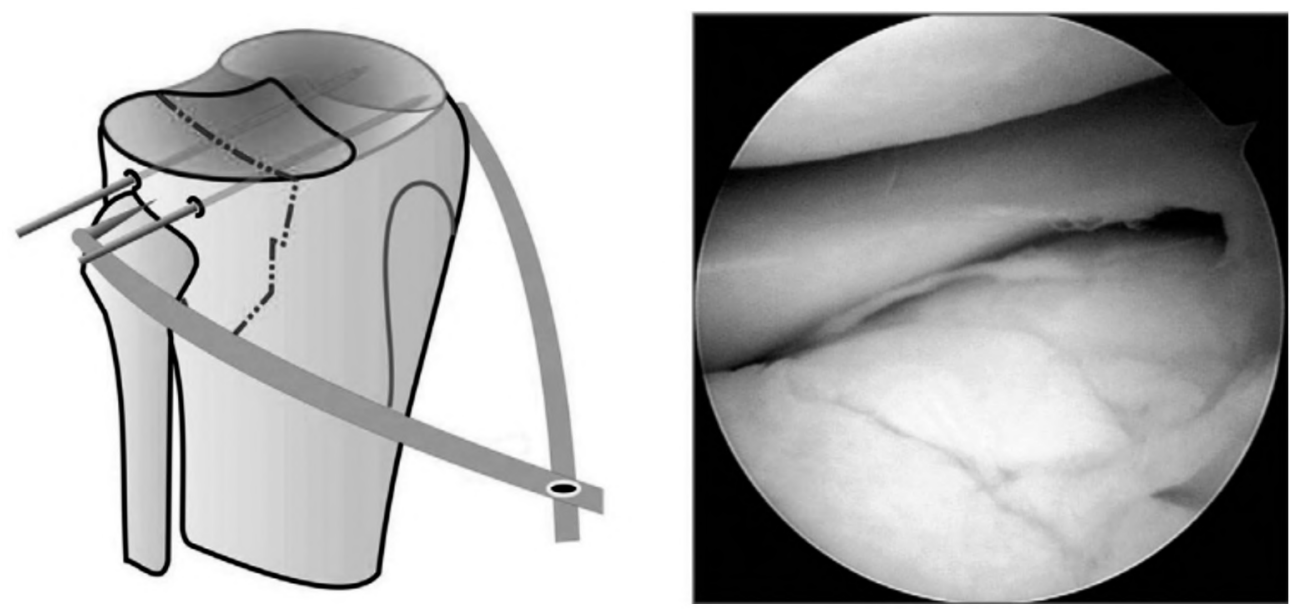

Fig. (4): Temporary stabilization was achieved using one or two pins.

\section{C- Schatzker type III fractures (lateral plateau central Depression):}

Fifteen patients with type III fracture underwent in many ways similar to the type II fractures in their surgical technique with the sequence of guide wire placement, fracture access via reamer and serrated hollow trephine cutter, elevation with tamp, temporary fixation percutaneously, bone grafting, and all of them were fixed with two cannulated or cancellous screws and washers.

\section{$D$ - Schatzker type $V$ fractures (lateral \& medial plateau fracture):}

There were four patients with type V fracture, all of them underwent ARIF technique, there were no associated articular surface depression. Avulsion of ACL and medial meniscal tear was present in one case (fixation was done in the same procedure), all cases were fixed with buttress plates \& screws on one side and cancellous screws and washers on the other side.

Of the 50 patients, 21 (42\%) received autogenous iliac bone graft; ( 9 type II, 8 type III and 4 type V).

\section{Treatment of other lesions:}

In all cases associated intra-articular pathology was noted and treated in the appropriate sequence after fracture fixation. Meniscal suturing were done for repairable six menisci; using (In Out In) technique, partial meniscectomy and trimming were done for eleven menisci as meniscal suturing were not feasible. All knees were examined before and after fracture fixation; collateral ligament lesions (mainly partial tear in 3 cases) were managed conservatively after stress valgus and varus tests. 4 ACL lesions were encountered (three cases in the form of partial rapture which treated conserv- atively) and one case of avulsion of tibial eminence which fixed in the same operation.

Immediate postoperative care included; Compressive ice, a knee brace and Continuous Passive Motion (CPM) were applied. Non-weight-bearing ambulation was restricted to the use of crutches or walkers until radiographic evidence of healing was noted.

\section{Clinical and radiologic assessment:}

The clinical and radiologic scales were recorded according to the Rasmussen system (Tables 2,3) [8]. The Rasmussen system was intended to improve upon the Hohl and Luck system by making it more quantitative. The advantage of the Rasmussen system is its analysis of both functional and anatomic end results for tibial plateau fractures after treatment. This scoring system was widely used in related studies of tibial plateau fractures [1]

The follow-up protocol included analysis of subjective complaints and objective clinical findings. All 50 patients completed a questionnaire regarding their overall function. Subjective data were collected to assess swelling, joint stability, ability to work and overall patient satisfaction with recovery. This radiological grading system evaluates the knee joint where depression of articular surface, condylar widening and angular deformities (valgus or varus) are taken into account with a possible total score of 18 points. A maximum of six points is attributed in each category. A score is not less than 18 points rates as an excellent result, 17 to 12 points as a good result. A fair result ranges from 11 to 6 points and a poor result is a score of less than 6 points. A radiographic evaluation, including examination of the knee, was done preoperatively and at 3 months and 6 months postoperatively and then annually thereafter. 
Table (2): Rasmussen Score (Criteria of Clinical assessment) $[8]$.

\begin{tabular}{|c|c|c|c|c|c|}
\hline Clinical Parameter & Points & Excellent & Good & Fair & Poor \\
\hline $\begin{array}{l}\text { Subjective: } \\
\text { Pain: } \\
\text { - None } \\
\text { - Occasional pain, } \\
\text { needs no medication } \\
\text { - Stabbing pain } \\
\text { - Intense, activity-related } \\
\text { - Night pain, at rest }\end{array}$ & $\begin{array}{l}6 \\
5 \\
4 \\
4 \\
2 \\
0\end{array}$ & 5 & 4 & 2 & 0 \\
\hline $\begin{array}{l}\text { Walking capacity: } \\
\text { - Normal } \\
\text { - Outdoors walking } \\
>1 \text { hour } \\
\text { - Outdoors walking } \\
<1 \text { hour } \\
\text { - Indoors only } \\
\text { - Wheelchair/bedridden }\end{array}$ & $\begin{array}{l}6 \\
5 \\
4 \\
1 \\
1 \\
0\end{array}$ & 6 & 4 & 2 & 1 \\
\hline $\begin{array}{l}\text { Objective: } \\
\text { Extension: } \\
\text { - Normal } \\
=>10^{\circ} \text { loss } \\
-<10^{\circ} \text { loss }\end{array}$ & $\begin{array}{l}6 \\
4 \\
2\end{array}$ & 6 & 4 & 2 & 2 \\
\hline $\begin{array}{l}\text { Total range of motion: } \\
->140^{\circ} \\
=>120^{\circ} \\
->90^{\circ} \\
->60^{\circ} \\
->30^{\circ} \\
-0^{\circ}\end{array}$ & $\begin{array}{l}6 \\
5 \\
4 \\
2 \\
1 \\
0\end{array}$ & 5 & 4 & 2 & 1 \\
\hline $\begin{array}{l}\text { Stability: } \\
\text { - Normal } \\
\text { - Abnormal in } 20^{\circ} \text { flexion } \\
\text { - Instability in extension } \\
\quad<10^{\circ} \\
\text { - Instability in extension } \\
>10^{\circ}\end{array}$ & $\begin{array}{l}6 \\
5 \\
4 \\
\\
2\end{array}$ & 5 & 4 & 2 & 2 \\
\hline Total (minimum) & & 27 & 20 & 10 & 6 \\
\hline
\end{tabular}

Table (3): Rasmussen Score criteria for radiological assessment [8]

\begin{tabular}{llllll}
\hline Parameter & \multicolumn{5}{c}{ Points Excellent Good Fair Poor } \\
\hline Depression: & 6 & 6 & 4 & 2 & 0 \\
$\quad$ None & 4 & & & & \\
$<5 \mathrm{~mm}$ & 2 & & & & \\
$6-10 \mathrm{~mm}$ & 0 & & & & \\
$>10 \mathrm{~mm}$ & & 6 & 4 & 2 & 0 \\
Condylar widening: & 6 & & & & \\
$\quad$ None & 4 & & & & \\
$<5 \mathrm{~mm}$ & 2 & & & & \\
$6-10 \mathrm{~mm}$ & 0 & & & & \\
$>10 \mathrm{~mm}$ & & 6 & 4 & 2 & 0 \\
Angulation (valgus/varus): & 6 & & & & \\
$\quad$ None & 4 & & & & \\
$<10^{\circ}$ & 2 & & & & \\
$10^{\circ}-20^{\circ}$ & 0 & & & & \\
$>20^{\circ}$ & & 18 & 12 & 6 & 0 \\
\hline Total (minimum) & & & & \\
\hline
\end{tabular}

\section{Results}

According to data of the patients; there was no significant relation between patient age, gender, or injured limb.

\section{A- Clinical assessment:}

Regarding fracture type clinical outcome were excellent results in 29 cases $58.0 \%$ (16 type I, 1 type II, and 12 type III) 19 had good results $38.0 \%$ ( 1 type I, 13 type II, 3 type III, and 2 type V), and 2 had fair results $4 \%$ (2 type V); in total, 48 patients $(96 \%)$ achieved satisfactory results Table (4).

Table (4): Clinical results regarding fracture type.

\begin{tabular}{|c|c|c|c|c|}
\hline & \multicolumn{3}{|c|}{ Clinical result } & \multirow{2}{*}{ Total } \\
\hline & Excellent & Good & Fair & \\
\hline \multicolumn{5}{|l|}{$\begin{array}{l}\text { Type of fracture: } \\
\text { I: }\end{array}$} \\
\hline Count & 16 & 1 & 0 & 17 \\
\hline $\begin{array}{l}\% \text { within type } \\
\text { of fracture }\end{array}$ & $94.10 \%$ & $5.90 \%$ & $0.00 \%$ & $100.00 \%$ \\
\hline \multicolumn{5}{|l|}{$I I:$} \\
\hline Count & 1 & 13 & 0 & 14 \\
\hline $\begin{array}{l}\% \text { within type } \\
\text { of fracture }\end{array}$ & $7.10 \%$ & $92.90 \%$ & $0.00 \%$ & $100.00 \%$ \\
\hline \multicolumn{5}{|l|}{ III: } \\
\hline Count & 12 & 3 & 0 & 15 \\
\hline $\begin{array}{l}\% \text { within type } \\
\text { of fracture }\end{array}$ & $80.00 \%$ & $20.00 \%$ & $0.00 \%$ & $100.00 \%$ \\
\hline \multicolumn{5}{|l|}{$V:$} \\
\hline Count & 0 & 2 & 2 & 4 \\
\hline $\begin{array}{l}\% \text { within type } \\
\text { of fracture }\end{array}$ & $0.00 \%$ & $50.00 \%$ & $50.00 \%$ & $100.00 \%$ \\
\hline \multicolumn{5}{|l|}{ Total: } \\
\hline Count & 29 & 19 & 2 & 50 \\
\hline $\begin{array}{l}\% \text { within type } \\
\text { of fracture }\end{array}$ & $58.00 \%$ & $38.00 \%$ & $4.00 \%$ & $100.00 \%$ \\
\hline
\end{tabular}

The difference between results in these group were not statistically significant $(p=0.000)$.

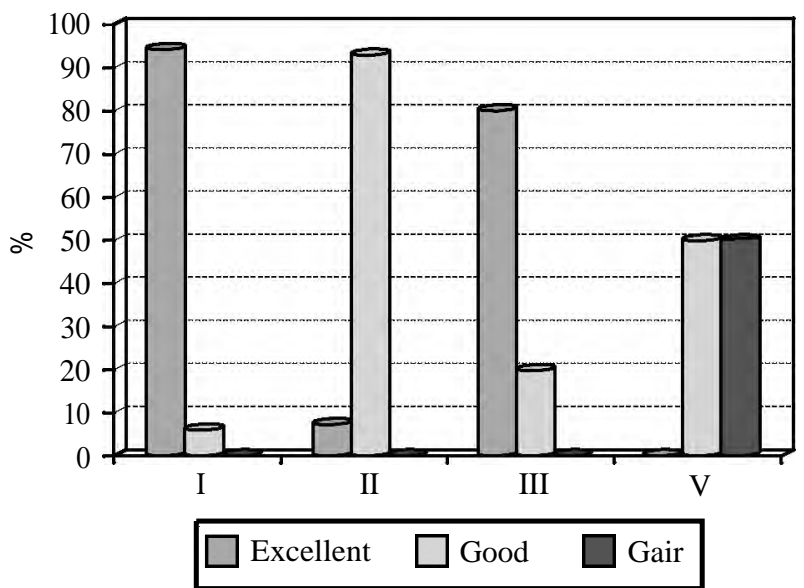

Fig. (5): Clinical outcome regarding fracture type. 


\section{B- Radiologic assessment:}

Radiologic results were excellent or good in $96 \%$ of cases; excellent results ( 22 cases $44.0 \%$ ) and good results (26 cases $52.0 \%$ ), and fair results in the other group ( 2 cases $4 \%$ ) which had the worst results, the mean radiological Rasmussen score were 17, with satisfactory results ( $p>.05)$. The mean time to achieve union was 9.12 weeks (range, 8 to 12 weeks), Table (5).

Table (5): Radiological results with the fracture type.

\begin{tabular}{|c|c|c|c|c|}
\hline & \multicolumn{3}{|c|}{ Radiographic result } & \multirow{2}{*}{ Total } \\
\hline & Excellent & Good & Fair & \\
\hline \multicolumn{5}{|l|}{$\begin{array}{l}\text { Type of fracture: } \\
\text { I: }\end{array}$} \\
\hline $\begin{array}{l}\text { Count } \\
\% \text { within type } \\
\text { of fracture }\end{array}$ & $\begin{array}{l}15 \\
88.20 \%\end{array}$ & $\begin{array}{l}2 \\
11.80 \%\end{array}$ & $\begin{array}{l}0 \\
0.00 \%\end{array}$ & $\begin{array}{l}17 \\
100.00 \%\end{array}$ \\
\hline \multicolumn{5}{|l|}{ II: } \\
\hline $\begin{array}{l}\text { Count } \\
\% \text { within type } \\
\text { of fracture }\end{array}$ & $\begin{array}{l}0 \\
0.00 \%\end{array}$ & $\begin{array}{l}14 \\
100.0 \%\end{array}$ & $\begin{array}{l}0 \\
0.00 \%\end{array}$ & $\begin{array}{l}14 \\
100.00 \%\end{array}$ \\
\hline \multicolumn{5}{|l|}{ III: } \\
\hline $\begin{array}{l}\text { Count } \\
\% \text { within type } \\
\text { of fracture }\end{array}$ & $\begin{array}{l}7 \\
46.70 \%\end{array}$ & $\begin{array}{l}8 \\
53.30 \%\end{array}$ & $\begin{array}{l}0 \\
0.00 \%\end{array}$ & $\begin{array}{l}15 \\
100.00 \%\end{array}$ \\
\hline \multicolumn{5}{|l|}{$V:$} \\
\hline $\begin{array}{l}\text { Count } \\
\% \text { within type } \\
\text { of fracture }\end{array}$ & $\begin{array}{l}0 \\
0.00 \%\end{array}$ & $\begin{array}{l}2 \\
50.00 \%\end{array}$ & $\begin{array}{l}2 \\
50.00 \%\end{array}$ & $\begin{array}{l}4 \\
100.00 \%\end{array}$ \\
\hline
\end{tabular}

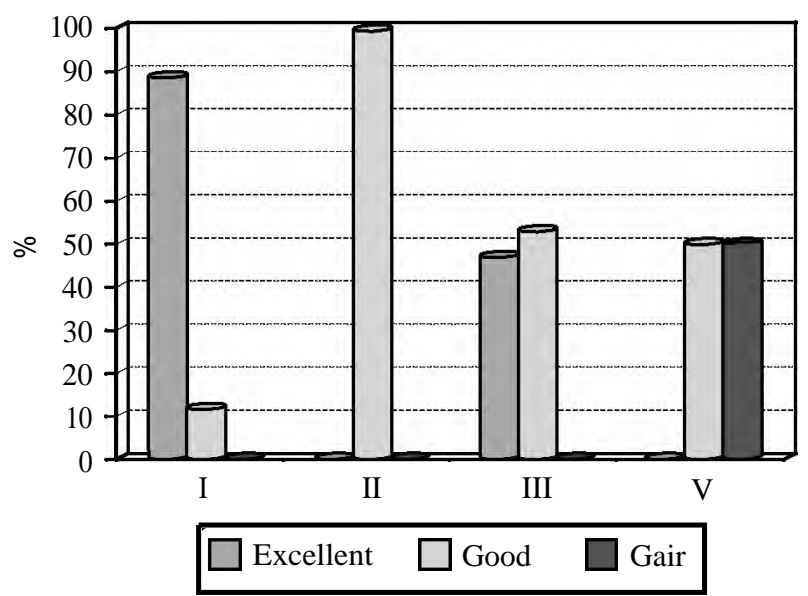

Fig. (6): Radiological results with the fracture type.

\section{Complications:}

Although the theoretic danger of compartment syndrome complicating arthroscopy for tibial plateau fracture warrants some caution, only 2 cases of highly suspicious of compartment syndrome in the leg after arthroscopic procedure of a tibial plateau fracture has been reported, by presence of the recognized signs, including tense posterior compartments and pain with passive stretching test, both cases were managed conservatively by closed observation, arterial \& venous Doplex, massive anti-edematous and pain killer drugs; and both cases were improved without surgical intervention. Three cases of infection were developed; First one, case no. (8) 56 years old female, fracture type III, Second one, case no. (35) 45 years old male, fracture type II with chronic bronchial asthma and on medical treatment $\&$ Third one, case no. (16) 57 years old male, fracture type II with type I DM; the three cases were managed as the first \& second cases of superficial infection; were improved with conservative treatment and strong Antibiotic administration according to culture \& sensitivity test; while the third case advanced to be deep infection and underwent to debridement for two times and ended with hardware removal with hinged knee brace using. Althoughtourniquet time was minimized (often $<2$ hours), and arterial supply and venous outflow were maximized. After deflation of the tourniquet, the legs were examined for pulse and distal circulation in the feet; two cases no. (21 type II and 34 type V fracture) were complaining of paresthesia over the lateral calf of the lower leg and both cases were improved spontaneously during follow-up period. One case developed Articular surface depression due to early weight bearing followed by surgical revision one month later to surgery.

\section{Discussion}

Tibial plateau fractures are articular lesions that threaten short- and long-term knee function. Their surgical management is often challenging. As with all articular fractures, the treatment goals consist of anatomic reduction, stable fixation consistent with early mobilization, and minimization of surgical trauma [7]. Open reduction introduces tremendous complication risks, especially in wound healing after traditional dissections [9]. Previous surgical methods achieved satisfactory results in $70 \%-80 \%$ of cases and have a high incidence of complications including loss of reduction, pin-tract infections, deep infection, and septic arthritis [7].

Arthroscopy-assisted surgical treatment for tibial plateau fractures is becoming more common due to its many advantages like direct visualization of intra-articular fractures, accurate fracture reduction, reduced morbidity in comparison with arthrotomy, simplified diagnosis and treatment of meniscal and ligamentous injuries, thorough-joint lavage, and removal of loose fragments [6]. 
Honkonen in 1994 described criteria for surgical intervention in tibial plateau fractures, which were: Step off equal to or exceeding $3 \mathrm{~mm}$ in the articular surface, condylar widening of up to $5 \mathrm{~mm}$, or a lateral tilt exceeding $10^{\circ} \mathrm{c}[3]$.

In our work we followed criteria of Honkonenfor ARIF patients were classified into four groups according to fracture type:

\section{Group A; type I tibial plateau fracture (split fracture):}

Seventeen patients of type I fracture managed with ARIF technique involved soft tissues injured management; 3 lat. \& one medial meniscus tear (treated by partial meniscectomy), one case of partial rupture of ACL (conservative treatment) Joy stick technique for reduction, fixation was achieved by using of 2-3 cancellous screws \& washers; with excellent results of all cases.

\section{Group B; type II tibial plateau fracture (split depression fracture):}

There were 14 patients with type II fracture associated with 5 lateral meniscal tear (3 of them treated by partial meniscectomy \& 2 treated by meniscus sutures), and 2 partial ACL rupture (for conservative treatment). ACL guide angle was used under arthroscopic assistance to place K-wire at the center of the depressed fragment followed by using of hollow serrated reamer to create metaphyseal window which used for elevation of depressed fragment and void filling (autologous bone graft) then fixation was done either by using of buttress plate \& screws or by 2-3 cancellous screws and washers with clinical results as; excellent 2 cases and good 13 cases.

Group C; type III tibial plateau fracture (isolated depression fracture):

Fifteen patients with type III fracture underwent to ARIF technique, 4 of them were associated with partial lateral meniscal tear ( 3 were treated by meniscal sutures \& one by partial meniscectomy), 2 medial meniscal tear were treated by partial meniscectomy, By using the same technique for reduction \& fixation of type II fracture the achieved clinical results were excellent in 12 cases and good in the other 3 cases according to Rasmussen score.

Group D; type V tibial plateau fracture (lateral \& medial plateau fracture):

There were four patients with type V fracture, with avulsion of ACL \& medial meniscal tear of one patient, and 2 lateral meniscal tear of other 2 patients; we used ARIF technique for all of them, buttress plate \& screws was used on one side and cancellous screws and washers on the other side. Achieved clinical results were good in 2 cases and fair in the other 2 cases.

Various soft-tissue injuries are common in the tibial plateau fracture and can be diagnosed by arthroscopy. Although some are merely minor injuries, many of these traumas can compromise the final outcome, and concomitant treatment of these soft-tissue injuries during fracture site fixation can cause major difficulties [10]. Arthroscopy provides a safe, quick, and accurate method of diagnosis and treatment. The arthroscopic methods previously reported by The Authors provided an excellent view of all knee joint structures, thus enabling accurate diagnosis and treatment of intraarticular fractures and related injuries [11]

In comparison with other studies, Gill T., et al. in 2001 used (ARIF) technique in 25 patients; the mean age was 45 years, mean follow-up period 24 months, tibial plateau fracture types (2 Type I, 5 Type II, 16 Type III, and 2 Type IV) and the results were $76 \%$ of patients rated their result as excellent and $16 \%$ as good \& $8 \%$ fair [12]. Pogliacomi F, et al., in 2005 has been used the same technique in 18 patients; the mean age was 49 years, mean follow-up period 12 months, tibial plateau fracture types (4 Type I, 6 Type II, 6 Type III, and 2 Type IV) and the results were $45 \%$ of patients excellent and $37 \%$ as good $\& 12 \%$ fair \& $6 \%$ were poor [13] Chan and Yuan; in 2011 used (ARIF) technique in 54 patients; the mean age was 48 years, mean follow-up period 87 months, tibial plateau fracture types (1 Type I, 21 Type II, 4 Type III, and 10 Type IV, 8 type V \& 10 type VI) and the results were $94 \%$ of patients rated their result as excellent and $3 \%$ as good \& $3 \%$ fair [6]

Gill T, et al., in 2001, Pogliacomi F, et al., in 2005 and Chan and Yuanin 2011 all have evaluated difficulties, complications and outcomes of arthroscopic assistance in reduction and fixation of tibial plateau fractures. We compared the results \& complications of this study with these authors studies in order to obtain a substantial comparative analysis (Tables 6).

All 50 patients in this series were treated by use of arthroscopy-assisted surgery, and the associated soft-tissue injuries were accurately diagnosed during surgery. 
Table (6): Comparison of the results.

\begin{tabular}{|c|c|c|c|c|}
\hline & Gill T.J., et al. & Pogliacomi F, et al. & Chan and Yuan & Our study \\
\hline No. of patients & 29 patients & 18 patients & 54 patients & 50 patients \\
\hline Mean age & 45 years & 49 years & 48 years & 28 years \\
\hline Mean follow-up period & 24 months & 12 months & 87 months & 10 months \\
\hline Associated Injuries & $\begin{array}{c}16(64 \%) \text { as; } 8 \mathrm{LMt}, 1 \\
\text { MMT, 1MCL, 5ACL, } \\
1 \text { complete tear ACL }\end{array}$ & $\begin{array}{l}7(39 \%) ; \text { as 4LMT, } \\
\text { 1MMT, 1ACL \&, } 1 \\
\text { PCL tear }\end{array}$ & $\begin{array}{l}(65 \%) \text { as; } 21 \text { meniscal } \\
\text { tear }(15 \mathrm{LMT}, \\
\text { 3MMT }) ; 8 \text { partial } \\
\text { ACLT, and } 1 \text { MCLT }\end{array}$ & $\begin{array}{l}21(42 \%) \text { as; } 13 \mathrm{LMT} \\
\text { 4MMT, 3ACLT and } \\
\text { one avulsion ACL }\end{array}$ \\
\hline Hardware fixation & $\begin{array}{l}\text { Only } 3 \text { AO } 7.3 \mathrm{~mm} \\
\text { cannulated screws } \\
\text { and washers for each } \\
\text { case }\end{array}$ & $\begin{array}{l}\text { Only two cancellous } \\
\text { bone screws for each } \\
\text { case }\end{array}$ & $\begin{array}{l}\text { Either by buttress plate } \\
\& \text { screws or } \\
\text { cannulated and } \\
\text { cancellous screws }\end{array}$ & $\begin{array}{l}\text { Either by buttress plate } \\
\& \text { screws or } \\
\text { cannulated and } \\
\text { cancellous screws }\end{array}$ \\
\hline $\begin{array}{l}\text { Type of Fracture } \\
\text { (Schatzker classification) }\end{array}$ & $\begin{array}{l}\text { Two Type I, five Type } \\
\text { II, } 16 \text { Type III, and } \\
\text { two Type IV }\end{array}$ & $\begin{array}{l}4 \text { type I, } 6 \text { type II } 6 \text { type } \\
\text { III, and } 2 \text { type IV }\end{array}$ & $\begin{array}{l}1 \text { type I, } 21 \text { type II, } 4 \\
\text { type III, } 10 \text { type IV } \\
\text { and } 10,8 \text { type V were } \\
\text { type VI }\end{array}$ & $\begin{array}{l}17 \text { type I, } 14 \text { type II, } \\
15 \text { type III and } 4 \text { type } \\
\text { V }\end{array}$ \\
\hline Mean time to union (wk) & Not reported & Not reported & $10 \mathrm{Wks}$ & $9 \mathrm{Wks}$ \\
\hline $\begin{array}{l}\text { Mean Clinical } \\
\text { (Rasmussen Score) }\end{array}$ & $\begin{array}{l}27.5 \text { as } 76 \% \text { excellent, } \\
16 \% \text { good and } 8 \% \\
\text { was fair }\end{array}$ & $\begin{array}{l}45 \% \text { excellent, } 37 \% \\
\text { good, } 12 \% \text { fair and } \\
6 \% \text { were poor }\end{array}$ & $\begin{array}{l}28.4 \text { as; } 943 \% \\
\text { excellent, } 3 \% \text { good } \\
\text { and } 3 \% \text { fair }\end{array}$ & $\begin{array}{l}26 \text { as; } 58.0 \% \text { excellent, } \\
38 \% \text { good and } 4 \% \text { fair }\end{array}$ \\
\hline $\begin{array}{l}\text { Mean Radiographic } \\
\text { (Rasmussen Score) }\end{array}$ & Not reported & $\begin{array}{l}5(29 \%) \text { excellent, } 7 \\
(39 \%) \text { good, } 4(32 \%) \\
\text { fair and } 2(16 \%) \text { were } \\
\text { poor }\end{array}$ & $\begin{array}{l}16,1 \text { as } 59 \% \text { excellent, } \\
33 \% \text { good, and } 8 \% \\
\text { were fair }\end{array}$ & $\begin{array}{l}17(96 \%) \text { as; excellent } \\
(22 \text { cases } 44.0 \%) \text { and } \\
\text { good }(26 \text { cases } \\
52.0 \%) \text {, and fair ( } 2 \\
\text { cases } 4 \%)\end{array}$ \\
\hline Void filler & $\begin{array}{l}\text { Bone graft substitute in } \\
17 \text { patients }(64 \%)\end{array}$ & $\begin{array}{l}2 \text { patients autologous } \\
\text { bone grafting }\end{array}$ & $\begin{array}{l}(55 \%) \text { received } \\
\text { autogenous iliac bone } \\
\text { graft alone and } 23 \\
(43 \%) \text { received } \\
\text { allogeneic bone graft }\end{array}$ & $\begin{array}{l}21(42 \%) \text { received } \\
\text { autogenous iliac bone } \\
\text { graft; ( } 9 \text { type II, } 8 \\
\text { type III and } 4 \text { type V) }\end{array}$ \\
\hline $\begin{array}{l}\text { Pos op. Complications } \\
\text { Compartment syndrome }\end{array}$ & Two patients & & & Two cases \\
\hline $\begin{array}{l}\text { Infection } \\
\text { Stiff knee }\end{array}$ & & & & Three cases \\
\hline $\begin{array}{l}\text { Articular surface } \\
\text { depression }\end{array}$ & One patient & Two cases & One case & One case \\
\hline $\begin{array}{l}\text { Neurological } \\
\text { complications }\end{array}$ & & & $\begin{array}{l}5 \text { cases of peroneal } \\
\text { nerve neurapraxia }\end{array}$ & $\begin{array}{l}2 \text { cases of peroneal } \\
\text { nerve neurapraxia }\end{array}$ \\
\hline Vascular complications & & & & $\begin{array}{l}\text { Only one case of post } \\
\text { op. Popliteal artery } \\
\text { spasm }\end{array}$ \\
\hline
\end{tabular}

\section{Conclusion:}

Minimally invasive surgical techniques have gained popularity over the recent years and try to prevent additional surgical trauma to the knee joint by using a minimally invasive approach. The arthroscopic surgical treatment has many advantages include: Better visualization of the articular surfaces, better reduction of the fracture, better anatomical restoration of the joint surface, the possibility to assess and treat the associated intraarticular ligamentous and meniscal injuries, the possibility, through joint lavage, to remove loose fragments. 50 patients were underwent ARIF tech- nique; 32 males \&18 females, there were 17 type I, 14 type II, 15 type III and 4 type V fractures according to Schatzker's classification. The average age at operation was 28 years (range, 19 to 56 years), follow-up period had ranged from (6-12) months with an average of 10 months.

Rasmussen Score (clinical \& radiological) was used for post operative evaluation with these results; Mean Clinical Score 26/30 as; $58.0 \%$ excellent, $38 \%$ good and $4 \%$ fair \& Mean Radiographic Score $17 / 18$ as; excellent ( 22 cases $44.0 \%$ ) and good (26 cases $52.0 \%$ ), and fair ( 2 cases $4 \%$ ). 


\section{Conclusion:}

In agreement with other Authors we concluded that ARIF technique was highly suggested to do in tibial plateau fracture (Schatzker type I and III), suggested to do in non comminuted type II, while it is not recommended in comminuted type II and not suggested to do in the other three types (Schatzker type IV, V and VI) due to difficulty in reduction, high susceptibility of arthroscopy fluid extravasation and compartment syndrome.

\section{References}

1- CHAN Y.S., CHIU C.H., LO Y.P., CHEN A.C.Y., HSU K.Y., WANG C.J. and CHEN W.J.: Arthroscopy-assisted surgery for tibial plateau fractures. Arthroscopy, 24: 7608, 2008.

2- HARRIS L.N., MARK L., PEVNY T. and ANDREW I.: Arthroscopic management of tibial plateau fractures. Techniques in Knee Surgery, 6 (1): 9-16, 2007.

3- HONKONEN S.E.: Indications for surgical treatment of tibial condyle fractures. Clin. Orthop. Relat. Res., 302: 199 Y 205, 1994

4- SCHATZKER J., McBROOM R. and BRUCE D.: The tibial plateau fracture: The Toronto experience 19681975. Clin. Orthop., 138: 94-104, 1979.

5- EGOL K. and KOVAL K.J.: Fractures of the Proximal Tibia. In: Bucholz, Robert W., Heckman, James D.; CourtBrown, Charles M. (Eds) Rockwood \& Green's Fractures in Adults, 6th Edition. Lippincott Williams \& Wilkins Publishers, ch (50): 1999-2031, 2007.

6- CHAN Y.: Arthroscopy-assisted surgery for tibial plateau fractures. 2 to 10-year follow-up results. Chang Gung Med. J., 34: 239-47, 2011

7- BURDIN G.: Arthroscopic management of tibial plateau fractures: Surgical technique. Orthopaedics \& Traumatology: Surgery \& Research, 99S: S208-S218, 2013.

8- RASMUSSEN P.S.: Tibial condylar fractures. Impairmen of knee joint stability as an indication for surgical treatment. J. Bone Joint Surg. Am., 55A: 1331-1350, 1973.

9- TSCHERNE H. and LOBENHOFFER P.: Tibial plateau fractures: Management and expected results. Clin. Orthop. Relat. Res., 87-100, 1993.

10- HUNG S.S., CHAO E.K. and CHAN Y.S.: Arthroscopically-assisted osteosynthesis for tibial plateau fractures. Trauma, 54: 356-363, 2003.

11- CHAN Y.S., YUAN L.J. and HUNG S.: Arthroscopicallyassisted reduction with bilateral buttress plate fixation of complex tibial plateau fractures. Arthroscopy, 19: 974984, 2003.

12- GILL T.J., MOEZZI D.M., OATES K.M. and STERETT W.I.: Arthroscopic reduction and internal fixation of tibial plateau fractures in skiing. Clin. Orthop. Rel. Res., 383: 243-9, 2001.

13- POGLIACOMI F. and VERDANO M.A.: Combined arthroscopic and radio-scopic management of tibial plateau fractures: Report of 18 clinical cases. Acta Biomed Ateneo Parmense, 76: 107Y114, 2005. 


\section{معالجة كسر سطح عظمة الظتبوب بمساعدة المظار الجراحى}

خلال العقود الثاثة الأخيرة انتشرت على نطاق واسع تقنية استخدام المنظار الجراحى فى معالجة كسر سطع عظمة القصبة لما له من

مزايا عديدة مثل:

- تفريغ التجمع الدموى وفتات العظام والفضاريف الناتجة عن الكسر من مفصل الركبة.

- تشخيص ومعالجة إصابات الأنسجة الرخوة من أربطة وغضاريف ملالية داخل مفصل الركبة فى نفس ذات العمات العملية. - رؤية سطح المفصل بوضوح أثثاء عمليتى الرد والتشييت.

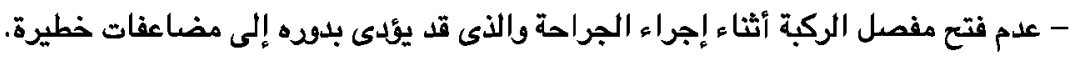

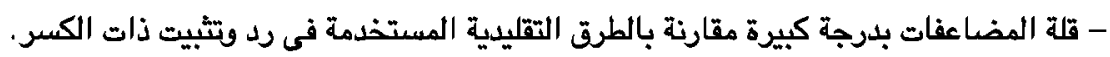

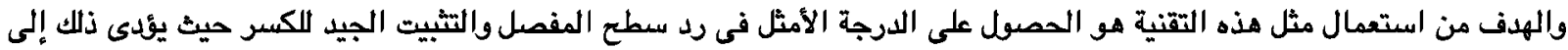

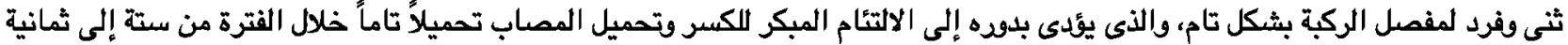
أسعابيع من إجراء الجراحة. طبقاً لتصنيف شاتزكر والذى يعد الاكثر شيوعاً بين جراحى العظام يوجد لكسر سطع عظمة القصبة ستة أنواع الأتى:

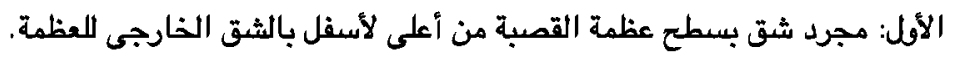

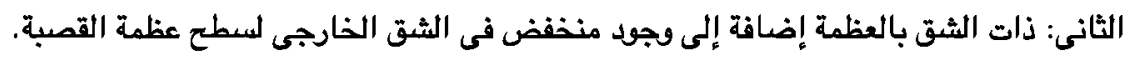
الثالث: مجرد انخفاض فى الثق الخارجى لسططح عظمة القصبة. الرابع: وجود كسر بالشق الداخلى السطح عظمة القصبة.

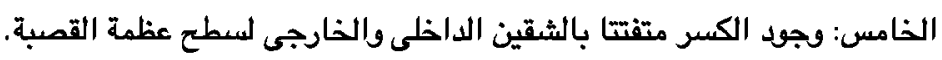
السادس: امتداد الكسر من النوع الخا مس إلى النصف الأعلى من العظمة. عند إجراء الجراحة يستعمل المنظار بالطريقة التقليدية وبعد تفريغ التجمع الدموى الناتج عن الكسر وغسل المفصل يتم استكثاف المفصل وصولا للتقييم الأمثل لبقية محتويات المفصل.

يتم رد الكسر من النوع الأفل بواسطة الشد على الأربطة الخارجية ويمسا عدة جهاز الأشعة الضوئية اللحظية والرؤية التامة للرد بواسطية

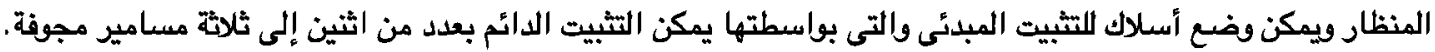

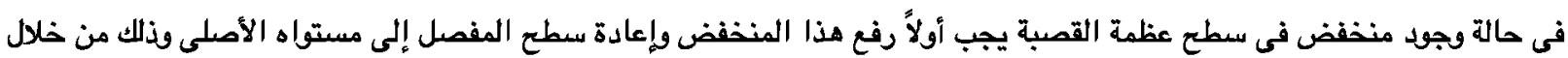

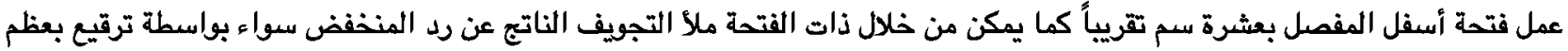

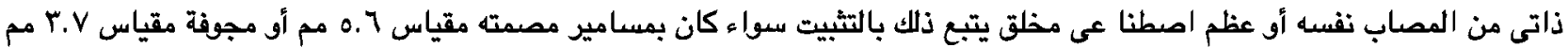

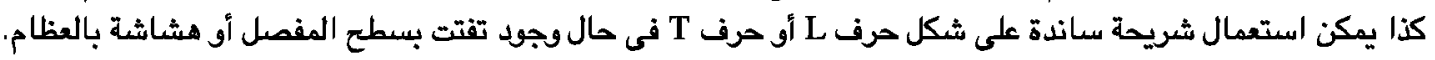

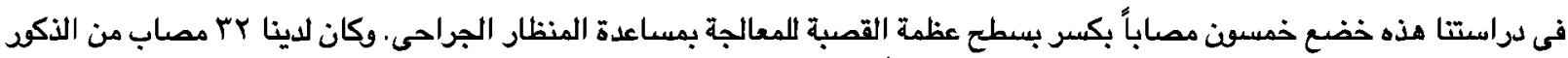
و I من الإناث بمتوسط عمر Y Y سنة تم تصنيفهم كالآتى (طبقاً لتصنيف شاتزكر): النوع الأول: VI مصاب. النوع الثانى: عا مصاب. النوع الثالث: 10 مصاب، إضافة إلى أربعة مصابين من النوع الخامس.

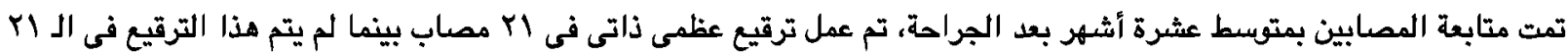

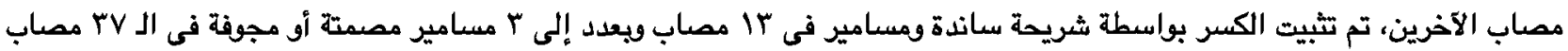

أجريت عملية تهذيب لقطع جزئى بالفضروف الهلالى لـ ل1 1 مصاب وخياطة لـ 7 غضاريف أخرى، وطبقاً لمقياس رازموسين والذى يعد الاكثر

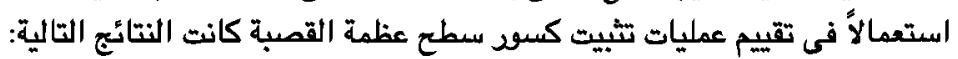

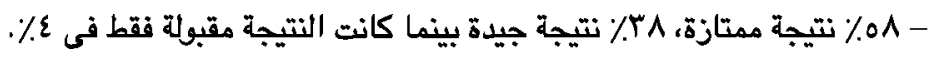

